\title{
Spectroscopic, Textural and Thermal Characterization Methods of Biostimulants Based on Sodium Humate
}

\author{
RUSANDICA STOICA ${ }^{1 *}$, FLORIN OANCEA ${ }^{1}$, IULIAN MINCA ${ }^{1}$, SANDA MARIA DONCEA ${ }^{1}$, RODICA GANEA ${ }^{1}$, LUIZA CAPRA ${ }^{1,2}$, \\ RALUCA SENIN ${ }^{1,2}$, MARIANA MATEESCU ${ }^{1}$, IRINA CIOBANU ${ }^{1}$, GEORGETA IVAN ${ }^{1,2}$, MIHAELA MANO LACHE ${ }^{1}$ \\ ${ }^{1}$ National Research \& Development Institute for Chemistry and Petrochemistry ICECHIM, 202 Splaiul Independentei Str., 060021, \\ Bucharest, Romania \\ 2University Politehnica of Bucharest, 313 Splaiul Independentei Str., 060042, Bucharest, Romania
}

\begin{abstract}
Plant biostimulants, an emerging class of agricultural inputs, are complex products. The reproducibility of their specific action on plant metabolism and plant physiology, which lead to an enhanced nutrient use efficiency, stress tolerance and edible yield quality, is still a challenge. Development of quality insurance systems for plant biostimulants need complex investigation based on adapted analytical, physico-chemical and chemical methods. The objective of this work was to characterize commercial humate biostimulants through different analytical techniques (Fourier transform infrared spectroscopy - FTIR, thermogravimetric analysis- TGA) and to evaluate their textural and chemical ( $\mathrm{pH}, \mathrm{C}, \mathrm{N}$, humic acids, inorganic components) parameters. The first derivative curve from TG analysis showed decomposition of different compounds, classified according to the results obtained by FTIR. The humic substances determined by TGA method waS comparable with the results obtained by gravimetric reference method. The inductively coupled plasmaoptical emission spectrometry (ICP-OES) technique was applied to determine the inorganic elements either from the production process of humate or from raw materials, as well as for the control of humate in terms of requirements for safety and quality. Their complementary properties obtaining through different analytical techniques provide essential information on the chemical characteristics of the humate plant biostimulant formulations.
\end{abstract}

Keywords: sodium humate; humic acids, FTIR, TGA, BET, ICP-OES, biostimulant

Plant biostimulants represent a new class of products used as inputs in the plant cultivation technologies, which act on plant biochemistry and physiology [1-3], increasing the water and nutrient uptake and use efficiency, enhancing the tolerance of cultivated plants to biotic and abiotic stress, improving crop quality, mainly due to a higher accumulation of the bioactive compounds into edible yield [4]. Most biostimulants currently used are complex mixtures of (bio)chemicals defined as a formulated product of biological origin that improves plant productivity as a consequence of the novel, or emergent properties of the complex of constituents, and not as a sole consequence of the presence of known essential plant nutrients, plant growth regulators, or plant protective compounds [5].

The main categories of biostimulants for plants, other than plant beneficial microorganisms [6] are: humic and fulvic acids [ 7]; protein hydrolysates / peptides and amino acids [8] and other amino derivatives compounds such as glycine-betaine [9]; algae [10, 11] and plants extracts [12]; beneficial elements [13], especially soluble silicon / silicic acid [14] and inorganic compounds as phosphite [15]; chitosan [16] and other biopolymers [17].

Humic substances (HS) are natural constituents of the soil organic matter, resulting from the decomposition of plant, animal and microbial residues, but also from the metabolic activity of soil microbes using these substrates. HS are collections of heterogeneous compounds, originally categorized according to their molecular weights and solubility into humins, humic acids and fulvic acids. Humic substances have been recognized for long as essential contributors to soil fertility, acting on physical, physicochemical, chemical and biological properties of the soil. Most biostimulant effects of HS refer to the amelioration of root nutrition, via different mechanisms [18].
Clearly, the reproducibility of the biological action of these bioproducts obtained from natural/renewable raw materials depends on their characterization and standardization. In order to achieve such characterization, which is indispensable for defining the regulatory framew ork for these bioproducts it is necessary to develop fast and accessible methods of analysis, used both in the obtaining process of these bioproducts and to demonstrate conformity with essential requirements of products for safety and quality.

The need for standardization is reflected by the establishment of a new CEN Technical Committee Plant Biostimulants and Agricultural Micro-organisms. This technical committee in the field of plant biostimulants and agricultural micro-organisms comes in support of EC proposal for the elaboration a new regulation which will extend the scope of the previous fertilizers regulation to several new product families, including biostimulants [2]

Different studies [19-21] have shown methodological approaches for the characterization of biostimulants, e.g. those based on brown macro-algae.

Despite the fact that comprehensive information on plant growth and yield studies of biostimulants exist, the chemical composition of these complex mixtures is much more difficult to obtain. The objective of this study was to characterize two commercial humate and its major humic fraction (humic acids) using the chemical, textural, thermic and spectroscopic methods. The humate biostimulants characterization was done considering the corroboration of the information obtained through different analytical techniques FTIR, BET, TGA, TOC/TN , ICP-OES. The results of our work can be useful for small and medium enterprises (SME), which are manufacturers of humates, for characterization of their bioproducts.

\footnotetext{
* email: rusandica.stoica@gmail.com; laborator.analize@icechim.ro
} 


\section{Experimental part}

\section{Materials and methods}

Chemicals and biostimulant formulations

The humic acids standard was purchased from SigmaAldrich, sodium hydroxide from Scharlau and hydrochloric acid from Merck. The Certipur ICP-element standard solution IV (Merck) and the Phosphor ICP standard (Merck), both with concentrations of $1000 \mathrm{mg}^{-1}$ were used for prepared standard solutions. The digestions of sodium humate samples were done using $\mathrm{HNO}, 65 \%$ and HF $48 \%$ purchased from Scharlau. Doubly distilled water was used to prepare the standard solutions. All reagents used in the experiments were of analytical grade. The commercial biostimulant formulation evaluated in this study was liquid (LH) and solid humate (SH).

\section{Reference method}

Humic substances determined by TGA method which is described below is based on the gravimetric method as a reference method. The alkaline extraction, separation, and determination of humic acids were performed as described in this reference [22].

\section{Fourier transform infrared spectroscopy}

The Fourier Transform Infrared Spectroscopy method, $\mathrm{FTIR}$, was used both by transmission technique, in $\mathrm{KBr}$ pellet for humic and fulvic acids and humate samples. Spectrum recordings were done on an Perkin Elmer FTIR Spectrum GX apparatus, from $4000 \mathrm{~cm}^{-1}$ to $400 \mathrm{~cm}^{-1}$ accumulating 32 spectra, at a resolution of $4 \mathrm{~cm}^{-1}$.

\section{Textural characterization}

Nitrogen physisorption was used to characterize and compare the textural properties of a humic acid standard and a commercial humate. The textural characteristics of the two samples were evaluated from nitrogen adsorption/ desorption isotherms recorded at the liquid nitrogen temperature using a Quantachrome Nova 2200e equipment. The standard Brunauer-Emmett-Teller (BET) equation was applied to calculate the specific surface area of the analyzed samples. The total pore volume was estimated from the amount of gas adsorbed at a relative pressure ( $p / p o)$ value close to unity. The pore size distribution was determined from the adsorption branch of the isotherm using Barrett-J oyner-Halenda $(\mathrm{BJ} \mathrm{H})$ model. The t-plot method was used to estimate the external surface of the humic materials [23]. Prior to adsorption measurements, amounts of 90-100 mg of each sample were vacuum - degassed at room temperature for $24 \mathrm{~h}$. The experimental data processing was performed using Nova Win version 11.03 software.

\section{Thermogravimetric analysis}

Analysis of the humate biostimulants and the humic acids standard was carried out using a TGA/SDTA 851 thermogravimetric analyser (Mettler Toledo). The samples and reference material were heated from room temperature to $900^{\circ} \mathrm{C}$ in alumina crucibles at a heating rate of $20^{\circ} \mathrm{C} \mathrm{min}^{-1}$ in air at a flow rate of $50 \mathrm{~mL} \mathrm{~min}{ }^{-1}$. The thermal weight loss characteristics were observed as thermograms and quantitative evaluations were carried out on the curves using STARe evaluation software as derivative thermograms.

Chemical analysis

The $\mathrm{pH}$ of the formulation was measured using $10 \%$ aqueous solution of the original product.

The elemental compositions of the samples were determined byinductively coupled plasma-optical emission spectroscopy (Optima 2100 DV ICP-OES System) instrument. Humate samples were digested using Multiwave 3000 (Anton Paar) model microwave digestion system. The RF power used was 1300 watts, plasma flow was $15 \mathrm{~L} / \mathrm{min}$, Auxiliary gas flow was kept at $0.2 \mathrm{~L} / \mathrm{min}$, Nebulizer Flow was kept at $0.8 \mathrm{~L} / \mathrm{min}$, and Pump Flow Rate was kept at $1.5 \mathrm{~L} / \mathrm{min}$. Plasma view was in the axial/ radial mode. Approximately $0.2 \mathrm{~g}$ of sample was weighed and transferred into a pressure-resistant PTFE (polytetrafluoroethylene) vessel, and the mixture of acids $\left(65 \% \mathrm{HNO}_{3}+48 \% \mathrm{HF}, 10: 2 \mathrm{~mL}\right.$ ) was added. The procedure mentioned above was following by the complexation stage with boric acid $\left(\mathrm{H}_{3} \mathrm{BO}_{3}\right)$. Boric acid is added following digestion to complex $\mathrm{F}$ in solution. The reaction mixture was subjected to an evaporation procedure in order to remove the acids after the final digestion. The ICP-OES measurements were performed for the diluted solutions. The standard solutions for calibration curves were made from reference standards Certipur ICP-element standard solution IV of $1000 \mathrm{mg} / \mathrm{L}$. Determination of $\mathrm{Cd}, \mathrm{Co}, \mathrm{Cr}, \mathrm{Cu}$, $\mathrm{Ni}, \mathrm{Pb}$ was achieved by constructing a multipoint standard curve covering the range of analyte concentrations in samples (2-100 $\left.\mu \mathrm{g} \cdot \mathrm{L}^{-1}\right)$. Analytical determination of selenium it was done on a calibration curve in the range 50- $300 \mu \mathrm{g} \cdot \mathrm{L}^{-1}$. Phosphorus analysis was performed on a calibrated curve containing standards with concentrations of 0.3-1 mg.L.'-1.

The determinations of TC (Total Carbon), TIC (Total Inorganic Carbon), TOC (Total Organic Carbon) were made using Multi N/C 2100 Analytic Jena AG-Germany. Standardized methods were performed as described in this reference $[24,25]$. After dilution, the samples were analyzed by difference method. The TOC is obtained by calculating the difference between TC and TIC. The carbon and nitrogen content of the samples were calculated using a previously determined calibration function.

\section{Results and discussions}

Fourier transform infrared spectroscopy

The FTIR spectra of humic and fulvic acids have basically the same types of absorption bands, and their spectra differs mainly by their relative intensity of this bands. For this reason all the spectra have been normalized and their baseline, corrected. The main recorded bands for humic acids, compared to those reported in the numerous literature studies [26- 29], figure 1, are: a broad band at $3600 \mathrm{~cm}^{-1}$ to $3200 \mathrm{~cm}^{-1}$ corresponding to the $\mathrm{H}-\mathrm{OH}$ bond from alcohols, phenols and organic acids, as well as intermolecular and/or intramolecular hydrogen bonds, and also to N-H groups; two bands at $2923 \mathrm{~cm}^{-1}$ and at 2852 $\mathrm{cm}^{-1}$ corresponding to the stretch vibration of the $-\mathrm{CH}_{2}$ group in the alkyl structures; a broad band at $1800 \mathrm{~cm}^{-1}$ to 1500 $\mathrm{cm}^{-1}$, with a shoulder at $1622 \mathrm{~cm}^{-1}$ corresponding mainly to the $\mathrm{C}=\mathrm{C}$ aromatic linkages and/or to the $\mathrm{C}=0$ group of Amide (I), ketone or quinone.

Also, a second shoulder is recorded at $1571 \mathrm{~cm}^{-1}$ to 1557 $\mathrm{cm}^{-1}$ characteristic to the $\mathrm{C}=0$ group of the Amide (II); a less intense band between $1459 \mathrm{~cm}^{-1}$ and $1377 \mathrm{~cm}^{-1}$ corresponding to several chemical groups such as: - $\mathrm{CH}_{3,}$ $\mathrm{OH}$ phenolic, $\mathrm{COO}$ - and/or ortho-disubstituted aromatic ring; a light band at $1272 \mathrm{~cm}^{-1}$ produced by Amide (III) and/or an ether as well as a broad band between 1240 $\mathrm{cm}^{-1}$ and $1140 \mathrm{~cm}^{-1}$ and between $1100 \mathrm{~cm}^{-1}$ and $950 \mathrm{~cm}^{-1}$, with sharp peaks centered at $1191 \mathrm{~cm}^{-1}$, at $1096 \mathrm{~cm}^{-1}$, at $1032 \mathrm{~cm}^{-1}$ and at $1009 \mathrm{~cm}^{-1}$, which generally characterize aromatic ethers, but also carbohydrates or silicates, which also absorb in these spectral zones. These characteristic absorption bands confirm the presence of strongly oxidized 


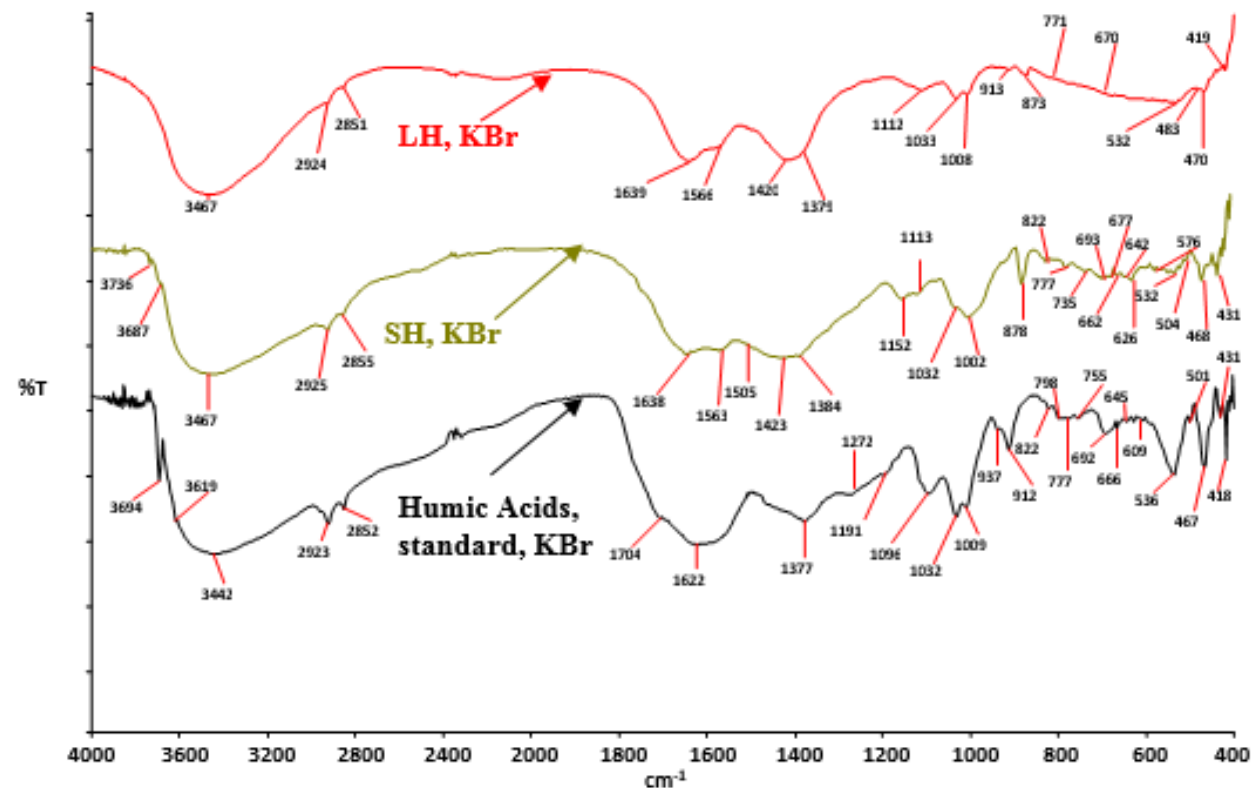

Fig.1. The FTIR spectra of liquid humate (LH); solid humate (SH) and humic acids standard in $\mathrm{KBr}$

humic acids, which is the basic structure of fulvic acids, which are in very good concordance with the literature [30-32]. The humates samples were analyzed both by transmission technique, in $\mathrm{KBr}$ pellet, and by attenuated total reflectance, in order to find out which spectral technique provides more information for their characterization. More informations have been obtained by transmission technique, and the main recorded absorption bands, in concordance with literature [33-37]. As a general feature, spectrum has a high absorption intensity for the three types of bands, namely: at 3400 $\mathrm{cm}^{-1}$, at $1650 \mathrm{~cm}^{-1}$ and at $1034 \mathrm{~cm}^{-1}$. The first corresponds to the hydrogen bond, $\mathrm{H}-\mathrm{OH}$, and/or the intermolecularand/ or intramolecular $\mathrm{OH}$ bond, of $\mathrm{OH}$... OH type, and/or the $\mathrm{NH}$ group, the second occurs mainlyin benzoic compounds and the third band mainly belongs to the $\mathrm{C}-\mathrm{O}-\mathrm{C}$ etheric bond.

\section{Textural characterization}

The $\mathrm{N}_{2}$ adsorption/desorption isotherms of humic acid and sodium humate (not shown here) are quite similar representing a combination of II and IV type isotherms according to IUPAC classification and indicate the mesoporous character of the two samples [38].

The textural parameters characterizing the porous structure and pore size distributions of the analyzed samples are presented in table 1 and figure 2 .

\section{Table 1}

TEXTURAL PARAMETERS OF HUMIC ACIDS STANDARD AND SODIUM HUMATE SAMPLE (SH)

\begin{tabular}{|c|c|c|c|c|c|}
\hline Sample & $\begin{array}{c}\mathrm{S}_{\mathrm{BET}} \\
\left(\mathbf{m}^{2} / \mathrm{g}\right)\end{array}$ & $\begin{array}{c}\mathrm{S}_{\text {ext }} \\
\left(\mathbf{m}^{2} / \mathrm{g}\right)\end{array}$ & $\begin{array}{c}\mathbf{V}_{\mathrm{t}} \\
(\mathbf{c c} / \mathrm{g})\end{array}$ & $\begin{array}{c}\mathbf{V}_{\mathrm{M}} \\
(\mathbf{c c} / \mathrm{g})\end{array}$ & $\begin{array}{c}\mathrm{D}_{\mathrm{p}} \\
(\mathbf{n m})\end{array}$ \\
\hline Humic acids & 2.59 & 2.59 & 0.009 & 0.009 & 3.54 \\
\hline Sodium humate & 1.45 & 1.45 & 0.003 & 0.003 & 4.29 \\
\hline
\end{tabular}

SBET: BET specific surface area; $S_{\text {ext: }}$ t-plot extemal surface area; $\mathrm{V}_{\mathrm{t}}$ : volume of gas adsorbed at $\mathrm{p} / \mathrm{p}_{\mathrm{o}} \sim 1.0 ; \mathrm{V}_{\mathrm{M}}$ : $\mathrm{BJH}$ mesopores volume; $\mathrm{D}_{\mathrm{p}}$ : $\mathrm{BJH}$ mesopores diameter.

As can be seen in table 1 , the both samples have low specific surface areas. The surface area and total pore volume of the sodium humate are smaller $\left(1.45 \mathrm{~m}^{2} / \mathrm{g}, 0.003\right.$ $\mathrm{cc} / \mathrm{g})$ ) as compared to humic acid $\left(2.59 \mathrm{~m}^{2} / \mathrm{g}, 0.009 \mathrm{cc} / \mathrm{g}\right)$. Generally, the surface areas of humic materials can vary in a large range in connection with their particular structure, composition, particle size, etc. $[39,41]$. Our data suggest that the investigated samples may have low chelating capacity with metal ions and low interaction with different
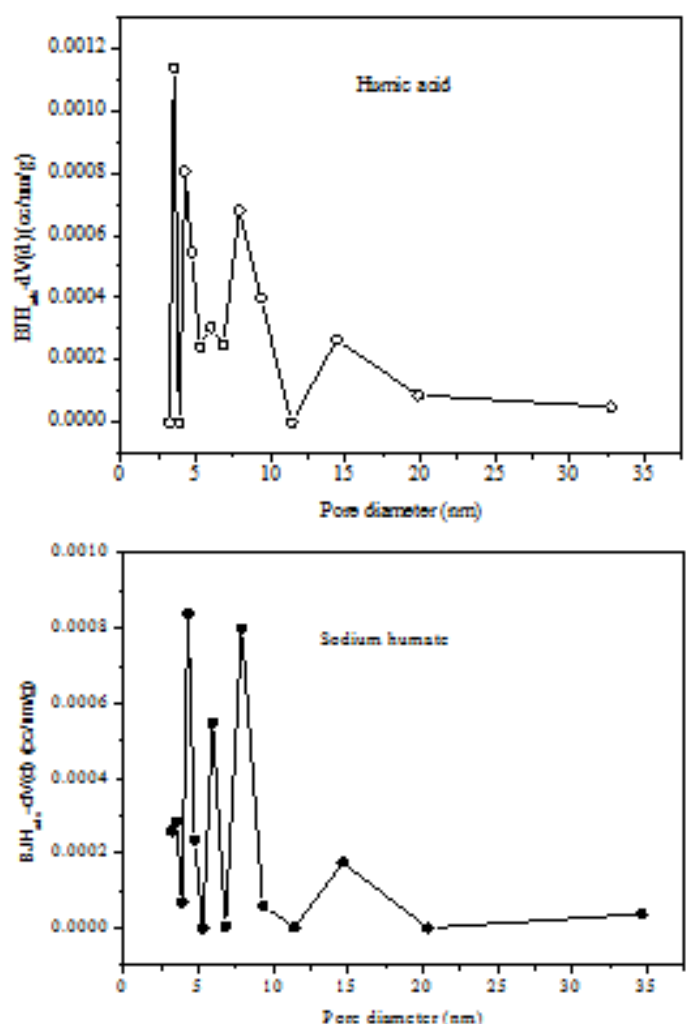

Fig.2.Pore size distributions of humic acids standard and sodium humate (SH)

organic compounds, which is due to their small specific surface areas. The pore size distributions in figure 2, evidence the mesoporosity of the humic acid and sodium humate investigated in this study. As can be seen in figure 2, humic acid has a quite narrow mesopores size distribution with a maximum situated at $3.54 \mathrm{~nm}$. Moreover, a significant proportion of larger mesopores of $5-20 \mathrm{~nm}$ is observed in humic acid.

The sodium humate sample is characterized by a multimodal pore size distribution in the mezzo region evidenced by the highest maximum centered at $4.29 \mathrm{~nm}$ followed by the other two quite intense maxima situated at $7 \mathrm{~nm}$ and $9 \mathrm{~nm}$, respectively.

As compared to humic acid, the presence of larger mesopores $(10-20 \mathrm{~nm})$ is also observed in sodium humate sample. It can be noted that the larger mesopores in sodium humate might result from the widening of the original mesopores during the activation process of the humic acid [40]. 


\begin{tabular}{|c|c|c|}
\hline Sample/standard & Determination & Results, \% \\
\hline \multirow{4}{*}{ Humic acids standard } & Mass loss between $25-200^{\circ} \mathrm{C}$ & 2.0 \\
\hline & Mass loss between $200-385^{\circ} \mathrm{C}$ & 15.4 \\
\hline & Mass loss between $385-900^{\circ} \mathrm{C}$ & 50.3 \\
\hline & Residue at $900^{\circ} \mathrm{C}$ & 32.3 \\
\hline \multirow{4}{*}{ Solide humate } & Mass loss between $25-280^{\circ} \mathrm{C}$ & 12.7 \\
\hline & Mass loss between $280-615^{\circ} \mathrm{C}$ & 10.0 \\
\hline & Mass loss between $615-900^{\circ} \mathrm{C}$ & 21.7 \\
\hline & Residue at $900^{\circ} \mathrm{C}$ & 55.6 \\
\hline \multirow{4}{*}{ Liquid humate } & Mass loss between $25-150^{\circ} \mathrm{C}$ & 86.1 \\
\hline & Mass loss between $150-550^{\circ} \mathrm{C}$ & 1.5 \\
\hline & Mass loss between $550-900^{\circ} \mathrm{C}$ & 4.4 \\
\hline & Residue at $900^{\circ} \mathrm{C}$ & 8.0 \\
\hline
\end{tabular}

Table 2

TGA RESULTS OF HUMIC ACID STANDARD AND HUMATE SAMPLES

Thermogravimetric analysis

Thermogravimetric (TG) and the corresponding differential thermogravimetric (DTG) curves for humic acids reference standard and humate samples are shown in figure 3 . In the DTG curves can be observed three regions with peaks between $25-150^{\circ} \mathrm{C}, 150-385^{\circ} \mathrm{C}, 385-9000^{\circ} \mathrm{C}$ for humic acids standard and $25-280{ }^{\circ} \mathrm{C}, 280-615{ }^{\circ} \mathrm{C}, 615-900$ ${ }^{\circ} \mathrm{C}$ for SH (table 2).

The DTG curve of humic acids standard presents a small peak around $100{ }^{\circ} \mathrm{C}$ and two exothermic peaks at about $340^{\circ} \mathrm{C}$ and at about $470^{\circ} \mathrm{C}$. The DTG curves of the solid humate sample exhibit a peak at $104^{\circ} \mathrm{C}$, small exothermic peaks at about $320^{\circ} \mathrm{C}$ and at about $460{ }^{\circ} \mathrm{C}$ and a strong exothermic peak at $708{ }^{\circ} \mathrm{C}$. Whereas the decomposition reactions of humic substances are not well separated the assignments of the peaks of DTG curves was performed considering the results obtained from FTIR corroborated with experiments previously reported [42].

The first step is attributed to the elimination of moisture for humic acids (HAs) and fulvic acids (FAs), the second step is due to decarboxylation and dehydration and the third step with peaks in $400-780^{\circ} \mathrm{C}$ can be attributed to the decomposition of condensed aromatic nucleus. The thermostable organo-mineral compounds from FAs are decomposed at higher temperature [42].

Humic substances determined by TGA method was based on the mass losses of the humic acid standard and humate samples and knowing the humic acids content of the standard determined by the reference method. Humic substances of the formulations determined by TGA method were $8.0 \%(\mathrm{LH})$ and $69.0 \%(\mathrm{SH})$ the differences from those obtained by the reference method may be due to the presence of other substances like fulvic acids. The HS were evaluated with this quick, cheap method, which does not require a complex preparation of the sample, the results obtained being comparable to those determined by the reference method (gravimetric).

\section{Chemical analysis}

The compositions of liquid humate (LH) and solid humate (SH) determined by gravimetric and TOC/TN methods are summarized in table 3.

The gravimetric dry matter (DM) content of the formulation was 12.1 (LH) and $91.4 \%$ (SH). Carbon total (TC) concentration of LH and SH samples obtained by TOC/ $\mathrm{TN}_{\mathrm{b}}$ method was $3.34 \%$ and $22.6 \%$, while N concentration was $0.08 \%$ and $0.6 \%$ with the resultant $\mathrm{C} / \mathrm{N}$ ratios of 41.8 to 37.7 (Table 3). Similar observations have been reported by other authors [43].

The variations of inorganic elements listed in table 4, showing a relationship between high residue contents of the formulations and high concentrations of sodium attributed to the production process of the humate samples.

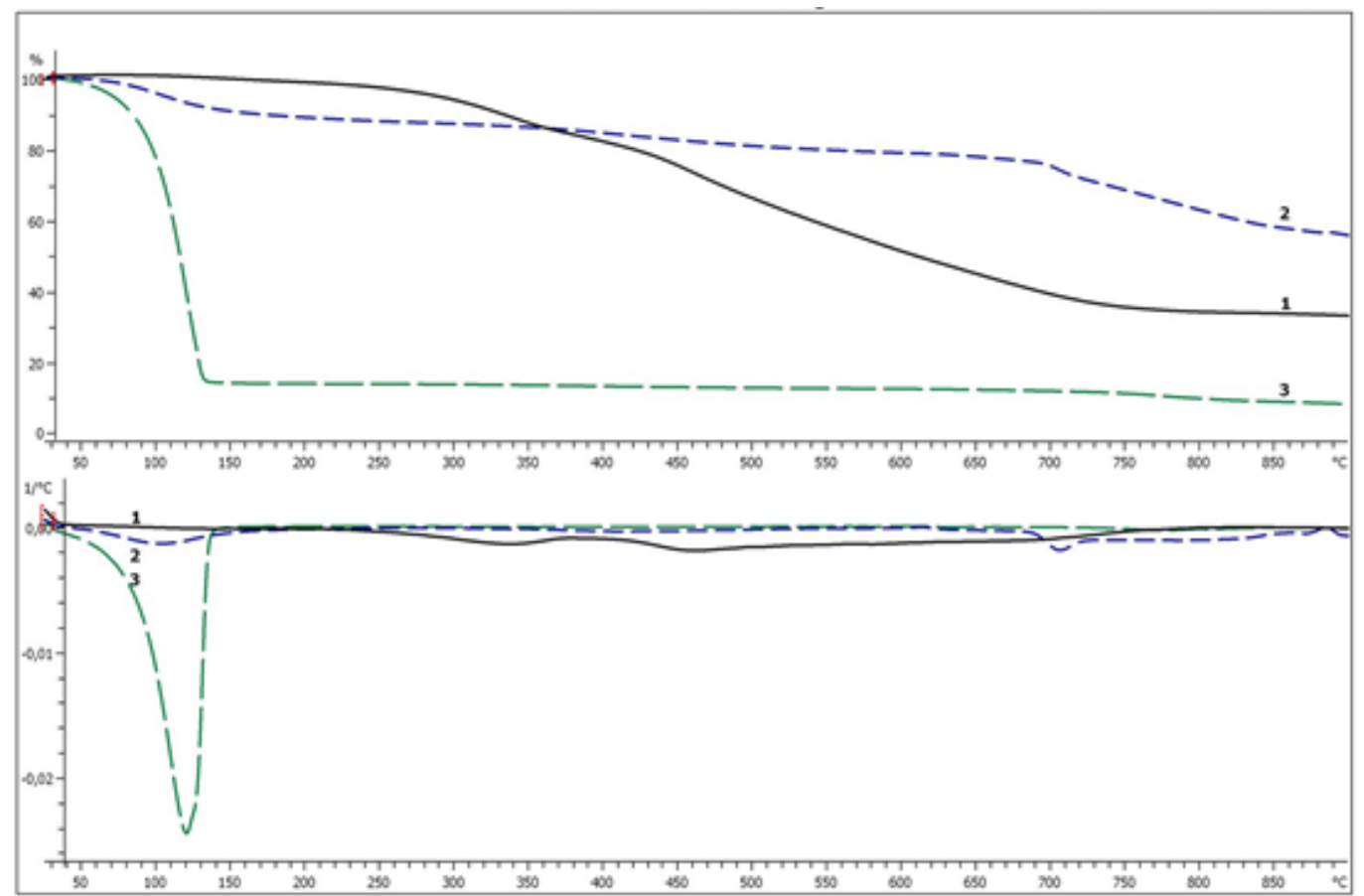

Fig. 3. The TG curves of 1- humic acids standard, 2- solid (SH) and 3-liquid humate (LH) 


\begin{tabular}{|c|c|c|c|}
\hline \multicolumn{2}{|c|}{ Formulation } & Liquid Humate & Solid humate \\
\hline \multicolumn{2}{|c|}{$\mathrm{pH}$} & 11.7 & 12.1 \\
\hline \multicolumn{2}{|c|}{ Dry matter, \% } & 12.08 & 91.38 \\
\hline \multicolumn{2}{|c|}{ TIC, $\%$} & 0.24 & 1.8 \\
\hline \multicolumn{2}{|c|}{$\mathrm{TC}, \%$} & 3.34 & 22.6 \\
\hline \multicolumn{2}{|c|}{ TOC, $\%$} & 3.10 & 20.8 \\
\hline \multicolumn{2}{|c|}{$\mathrm{TN}, \%$} & 0.08 & 0.6 \\
\hline \multicolumn{2}{|c|}{ C:N ratio } & 41.8 & 37.7 \\
\hline Reference method & Humic acids, \% & 6.49 & 65.9 \\
\hline TGA & Humic substances, $\%$ & 8.0 & 69.0 \\
\hline
\end{tabular}

Table 3

CHEMICAL CHARACTERISTICS OF DIFFERENT FORMULATIONS

\begin{tabular}{|c|c|c|c|c|}
\hline Sample & Element & $\begin{array}{c}\text { ICP-OES } \\
\text { Wavelength (nm) }\end{array}$ & Concentration & Unit \\
\hline \multirow{17}{*}{ Solid humate } & $\mathrm{Na}$ & 589.592 & 8.76 & $\%(w / w)$ \\
\hline & $\mathrm{Mg}$ & 285.213 & 0.238 & $\%(w / w)$ \\
\hline & $\mathrm{Ca}$ & 422.673 & 1.07 & $\%(w / w)$ \\
\hline & $\mathrm{K}$ & 766.490 & 0.58 & $\%(w / w)$ \\
\hline & $\mathrm{Al}$ & 396.153 & 1.51 & $\%(w / w)$ \\
\hline & $\mathrm{Fe}$ & 238.204 & 1.14 & $\%(w / w)$ \\
\hline & $\mathrm{Zn}$ & 213.857 & 0.027 & $\%(w / w)$ \\
\hline & Mn & 257.610 & 72.8 & $\mathrm{mg} / \mathrm{kg}$ \\
\hline & As & 228.812 & 0.518 & $\mathrm{mg} / \mathrm{kg}$ \\
\hline & $\mathrm{Cd}$ & 228.802 & $<1.3^{*}$ & $\mathrm{mg} / \mathrm{kg}$ \\
\hline & Co & 228.616 & $<0.8^{*}$ & $\mathrm{mg} / \mathrm{kg}$ \\
\hline & $\mathrm{Cr}$ & 267.716 & $<0.9^{+}$ & $\mathrm{mg} / \mathrm{kg}$ \\
\hline & $\mathrm{Cu}$ & 327.393 & $<0.9^{*}$ & $\mathrm{mg} / \mathrm{kg}$ \\
\hline & $\mathrm{Ni}$ & 231.604 & $<2.1^{*}$ & $\mathrm{mg} / \mathrm{kg}$ \\
\hline & $\mathrm{Pb}$ & 220.353 & 7.69 & $\mathrm{mg} / \mathrm{kg}$ \\
\hline & $\mathrm{Se}$ & 196.026 & 37.2 & $\mathrm{mg} / \mathrm{kg}$ \\
\hline & $\mathrm{P}$ & 213.617 & $<1.1^{*}$ & $\mathrm{mg} / \mathrm{kg}$ \\
\hline \multirow{17}{*}{ Liquid humate } & $\mathrm{Na}$ & 589.592 & 1.04 & $\%(w / w)$ \\
\hline & $\mathrm{Mg}$ & 285.213 & 0.027 & $\%(w / w)$ \\
\hline & $\mathrm{Ca}$ & 422.673 & 0.089 & $\%(w / w)$ \\
\hline & $\mathrm{K}$ & 766.490 & 0.011 & $\mathrm{mg} / \mathrm{kg}$ \\
\hline & $\mathrm{Al}$ & 396.153 & 0.090 & $\%(w / w)$ \\
\hline & $\mathrm{Fe}$ & 238.204 & 0.043 & $\%(\mathrm{w} / \mathrm{w})$ \\
\hline & $\mathrm{Zn}$ & 213.857 & 4.29 & $\mathrm{mg} / \mathrm{kg}$ \\
\hline & $\mathrm{Mn}$ & 257.610 & 6.99 & $\mathrm{mg} / \mathrm{kg}$ \\
\hline & As & 228.812 & 0.377 & $\mathrm{mg} / \mathrm{kg}$ \\
\hline & $\mathrm{Cd}$ & 228.802 & $<1.3^{*}$ & $\mathrm{mg} / \mathrm{kg}$ \\
\hline & Co & 228.616 & $<0.8^{*}$ & $\mathrm{mg} / \mathrm{kg}$ \\
\hline & $\mathrm{Cr}$ & 267.716 & $<0.9^{*}$ & $\mathrm{mg} / \mathrm{kg}$ \\
\hline & $\mathrm{Cu}$ & 327.393 & $<0.9^{+}$ & $\mathrm{mg} / \mathrm{kg}$ \\
\hline & $\mathrm{Ni}$ & 231.604 & $<2.1^{*}$ & $\mathrm{mg} / \mathrm{kg}$ \\
\hline & $\mathrm{Pb}$ & 220.353 & 4.47 & $\mathrm{mg} / \mathrm{kg}$ \\
\hline & $\mathrm{Se}$ & 196.026 & 30.1 & $\mathrm{mg} / \mathrm{kg}$ \\
\hline & $\mathrm{P}$ & 213.617 & $<1.1^{*}$ & $\mathrm{mg} / \mathrm{kg}$ \\
\hline
\end{tabular}

Table 4

MEASURED CONCENTRATIONS OF METALS FROM SODIUM HUMATE MATERIALS BY ICP-OES
The concentrations of $\mathrm{Cd}, \mathrm{Cr}, \mathrm{Pb}, \mathrm{Ni}$ can be assimilated to the raw materials being consistent with Annex 3 - Initial analysis for consideration by the CEN/TC Plant Biostimulants and Agricultural MicroOrganisms where is indicated for cadmium, Cr VI and lead a content of max. 3 $\mathrm{mg} / \mathrm{kg}$ dry matter, $2 \mathrm{mg} / \mathrm{kg}$ dry matter and $1020 \mathrm{mg} / \mathrm{kg}$ dry matter respectively [2].

\section{Conclusions}

Commercial humate, were characterized by various chemical, textural and instrumental methods. The results presented show that through the applied analytical techniques (FTIR, BET, TGA, TOC/TN , ICP-OES, gravimetry) the characterization the sodium humate samples was done based on their complementary chemical properties. The identification of major compounds was done byFTIR. As a general characterization of FTIR spectra for each of the three studied samples, one humic acids standard from Sigma Aldrich, and two commercial humates products, there have been observed three spectral zones: at about $3400 \mathrm{~cm}^{-1}$ for hydrogen bond, and/or $\mathrm{H}-\mathrm{OH}$, and/or the $\mathrm{NH}$ group, at about $1650 \mathrm{~cm}^{-1}$ mainly for unsaturated compounds, and at about $1034 \mathrm{~cm}^{-1}$ mainly for the $\mathrm{C}-\mathrm{O}-\mathrm{C}$ etheric bond. The humic acids are characterized especially 
by presence of $\mathrm{C}=0$ bound from $\mathrm{COO}$ groups at about $1704 \mathrm{~cm}^{-1}$ and of $\mathrm{OH}$ bound from $\mathrm{COOH}$ groups at about $912 \mathrm{~cm}^{-1}$. The sodium humates are characterized by presence of $\mathrm{C}=0$ bound from Amide I and/or aromatic $\mathrm{C}=\mathrm{C}$ skeletal at about $1638 \mathrm{~cm}^{-1}$ and of $\mathrm{N}-\mathrm{H}$ deformation and $\mathrm{C}=\mathrm{N}$ stretching of Amide $\|$ band at about $1563 \mathrm{~cm}^{-1}$.

Nitrogen physisorption data have evidenced the mesoporous structure of the humic acid and sodium humate. Taking into account the small specific surface areas, a limited number of organic compounds can be adsorbed on the investigated materials. Both humic acid and sodium humate have quite narrow mesopores size distributions. The larger mesopores size of sodium humate $(4.29 \mathrm{~nm})$ as compared to humic acid $(3.54 \mathrm{~nm})$ can be connected to the used activation process.

The quantitative information about organic and inorganic fractions from humate was obtained by TGA analysis. Humic substances of the formulations determined by TGA method were $8.0 \%(\mathrm{LH})$ and $69.0 \%$ (SH) the differences (1.5\% for $\mathrm{LH}$ and $3.1 \%$ for $\mathrm{SH}$ ) from those obtained by the reference method may be due to the presence of other substances like fulvic acids. The HS were evaluated with this quick, cheap method, which does not require a complex preparation of the sample.

Useful information for biostimulant producers results from the $\mathrm{N}$ content of the humate samples which in our case is much lower than the value reported by Schnitzer [44] of $3.2 \%$, for ideal humic acid soil makes simultaneous sources of inorganic $\mathrm{N}$ indispensable to prevent $\mathrm{N}$ deficiency in crops treated with these biostimulants.

The ICP-OES technique complete the information about the inorganic fraction thus sodium was assigned to the production process of humate biostimulants and $\mathrm{Mg}$, Se, $\mathrm{As}, \mathrm{Cd}, \mathrm{Co}, \mathrm{Cr}, \mathrm{Cu}, \mathrm{Pb}, \mathrm{Ni}$ and $\mathrm{P}$ were attributed to the humate raw materials.

The applied methods can be useful for humates caracterization necessary for the production of biostimulants with reproducible biological activity.

Acknowledgement: The research work for this paper was supported by ANCSI, through the SMART-PRIOCHEM Project, PN.16.31.01.02.02.

\section{References}

1.TRAON, A., AMAT, L., ZOTZ, F., JARDIN, P., Legal Framework for Plant Biostimulants and Agronomic Fertiliser Additives in the EU, 2014.

2.*** http://www.bds-bg.org/images/upload. Retrieved 06 23, 2017, from http://www.bds-bg.org/: http://www.bds-bg.org/images/upload/ Novini/10621.pdf

3.BULGARI, R., COCETTA, G., TRIVELLINI, A., VERNIERI, P.,

FERRANTE, A., Biol. Agric. Hortic., 31, no. 1, 2015, p. 1-17.

4.CALVO, P. N., NELSON, L., KLOEPPER, J. W., Plant Soil, 383, no.1, 2014, p. 3-41.

5.YAKHIN, O.I., LUBYANOV, A.A., YAKHIN, I.A., BROWN, P.H., Front. Plant Sci, 2017, p. 1-32.

6.LOPEZ-BUCIO, J., PELAGIO-FLORES, R., HERRERA-ESTRELLA, A., Sci. Hortic., 196, 2015, p. 109-123.

7.CANELLAS, L., OLIVARES, F., AGUIAR, N.O., JONES, D.L.,

NEBBIOSO, A., MAZZEI, P., et al., Sci. Hortic., 196, 2015, p. 15-27. 8.COLLA, G., NARDI, S., CARDARELLI, M., ERTANI, A., LUCINI, L., CANAGUIER, R., et al., Sci. Hortic., 196, 2015, p. 28-38.

9.CHEN, T.H.H., MURATA, N., Plant Cell Environ., 34, 2011, p. 1-20. 10.BATTACHARYYA, D., Z.BABGOHARI, M., RATHOR, P.,

PRITHIVIRAJ, B., Sci. Hortic., 196, 2015, p. 39-48.

11.SHARMA, H.S.S., FLEMING, C., SELBY, C., RAO, J.R., MARTIN, T., J. Appl. Phycol., 26, 2014, p. 465-90.

12.SANCHEZ-GOMEZ, R., ZALACAIN, A., ALONSO, G.L., SALINAS, M.R., J. Agr. Food Chem., 62, 2014, p. 10861-10872.
13.PILON-SMIT, E.A.H., QUINN, C.F., TAPKEN, W., MALAGOLI, M., SCHIAVON, M., Curr. Opin. Plant Biol., 12, 2009, p. 267-274

14.SAVVAS, D., NTATSI, G., Sci. Hortic., 196, 2015, p. 66-81.

15.GOMEZ-MERINO, F.C., TREJ O-TELLEZ, L.I., Sci. Hortic., 196, 2015, p. 82-90.

16.PICHYANGKURA, R., CHADCHAWAN, S., Sci. Hortic., 196, 2015, p. 49-65.

17.TROUVELOT, S., HELOIR, M.-C., POINSSOT, B., GAUTHIER, A., PARIS,

F., GUILLIER, C., et al., Front.. Plant Sci., 5, 2014, p. 592.

18.J ARDIN, P. D., SCi. Hortic., 2015, p. 1-12.

19.ROSS, A.B., ANASTASAKIS, K., KUBACKI, M., JONES, J.M., J. Anal.Appl. Pyrol., 85, 2009, p. 3-10.

20.SHARMA, S.H.S., LYONS, G., MCROBERTS, C., MCCALL, D., CARMICHAEL, E., ANDREWS, F., et al., J. Appl. Phycol., 24, no. 5, 2012, p. 1141-1157.

21.SUMMERER, S., PETROZZA, A., CELLINI, F., Acta Hortic., 1009, 2013, p. 143-148.

22.*** Humic Acid Method, Fertilizer Laboratory, California:

Department of Food and Agriculture, Center for Analytical Chemistry, 2009;

23.ROQUEROL, J., AVNIR, D., FAIRBRIDGE, C. W., EVERETT, D. H., HAYNES, J. M., PERNICONE, N., RAMSAY, J. D. F., SING, K. S. W., UNGER, K. K., Pure Appl. Chem., no. 66, 1994, p. 1739-1758.

24.*** SR EN 1484:2006, Water analysis. Guidelines for the determination of total organic carbon (TOC) and dissolved organic carbon (DOC).

25.*** SR EN 12260:2004, Water quality-Determination of nitrogenDetermination of bound nitrogen $\left(\mathrm{TN}_{\mathrm{b}}\right)$, following oxidation to nitrogen oxides.

26.BELLAMY L, J., The infrared spectra of complex molecules, 3rd ed., Vol. 1, Chapman and Hall, London, 1975.

27.GERASIMOWISZ, W.V., BYLER, D.M., Soil Sci., 139, 1985, p. 270278.

28.HERNANDEZ, M.T., MORENO, J.I., COSTA, F., GONZALEZ-VILA, F.J., FRUND, R., Soil Sci., 149, 1990, p. 63-68.

29.SCHNITZER, M., Humic Substances: their structure and function in biosphere, Nieuwerslius. Pudoc., 1972, p. 293-310.

30.STEVENSON, F.J.,Geochemistry of soil HS, John Wiley \& Sons, AIKEN, G.R., MCKNIGHT, D.M., WERSHAW, R.L., MACCARTHY, P., New York, 1985.

31.STEVENSON, F.J., Humus Chemistry, second ed., John Wiley and Sons, New York, 1994.

32.HELAL, A.A.,.J. Saudi Chem. Soc., 11, no. 3, 2007, p. 377-386.

33.STEVENSON F.J., Humus Chemistry: Genesis, Composition, Reactions, Wiley-Interscience, New York, 1994.

34.SENES, N., D'ORAZIO, V., RICCA, G., Geoderma, 116, 2003, p. 325344.

35.ERTANI, A., FRANCIOSO, O., TUGNOLI, V., RIGHI, V., NARDI, S., Food Chem., 59, 2011, p. 11940-11948.

36.RODRIGUEZ-LUCENA, P., LUCENA, J J., HERNANDEZ-APAOLAZA, L., Proc. 15th Int. Plant Nutrition Colloquium, UC Davis, Sacramento, 2009.

37.RADU, E., OPRESCU, E.E., ENASCUTA, C.E., CALIN, C., STOICA, R., SCAETEANU, V.G., VASILIEVICI,G., CAPRA, L., IVAN,G., ION, A.C., Rev. Chim. (Bucharest), 69, no. 1, 2018, p. 192.

38.THOMMES, M., Chemie Ing. Tech., no. 82, 2010, p.1059-1073.

39.ATKINS, P. W., Phys. Chem., PWN Warsaw, 2007, p. 830-832.

40.GOMES DEL MELO, B. A,. MOTTA, F. L., SANTANA, M. H. A., Mater. Sci. Eng. C, 62, 2016, p. 962-974.

41.MA, M. G., WEI, Y. X., ZHAO, G. H., LIN, F., ZHU, Y. R., Int. J. Environ. Protection and Policy no. 2, 2014, p. 230-235.

42.ZUYI, T., SHIFANG, L., ZHI, Z.F., YUHUI. Y., Chemistry And Ecology, 14, no.1, 1997, p.21-30.

43.LODHI, A., S.TAHIR, S., IQBAL, Z., MAHMOOD,A., AKHTAR, M., QURESHI T.M. , YAQUB, M., NAEEM, A., Soil Environ., 32, no.1, 2013, p. 63-70.

44.SCHNITZER, M., Humic substances: Chemistry and reactions, Elsevier, SCHNITZER, M., KHAN, S.U., New York, 1978, p. 1-64.

Manuscript received: 19.02 .2018 